\title{
INCOME TAXATION REGIMES FOR PRIVATE ENTREPRENEURS IN HUNGARY AND THE SLOVAK REPUBLIC

\author{
Norbert Gyurián ${ }^{1}$, Ádám Szobi ${ }^{2}$, Angelika Kútna ${ }^{3}$, Dániel Halasi ${ }^{4}$
}

\begin{abstract}
Private entrepreneurs have an important role in national economies worldwide. Most of them operate and assume legal obligations as private persons. Consequently, they are taxed pursuant to the legal regulations pertaining to personal income taxation in the respective countries. Incomes tax from individual activities is a substantial source of proceeds for national budgets. When taxes are imposed on the individual activities of private persons, they act as both taxable entities and taxpayers at the same time. They are obliged to account for the payable amount of taxes with the state, and present all the associated, necessary records. Therefore, the persons in question are to shoulder considerable administrative burdens. This aspect surfaces in increasing costs, because in most cases they have to rely on external, professional services. Countries aim at shaping taxation environments that encourage taxable persons to account for and state their own taxes. In pursuing this goal, most states have adopted several methods that allow the simpler quantification of the amounts of taxes beyond the scope of complicated accounting systems. This paper has set the objective to look into these methods in Hungary and the Slovak Republic.
\end{abstract}

JEL Classification Numbers: H24, H25, DOI: 10.12955/cbup.v7.1351

Keywords: Personal Income Tax, Business Income, Tax Base

\section{Introduction}

Private entrepreneurs take a key role in the operation of national economies. With respect to the incomes originating from their activities, the majority of them - as private persons - belong to personal income tax regimes. Unlike large companies, their operations tend to be less complex. It is necessary for the states to make this fact broadly acknowledged, and frame legal regulations that properly consider this situation. It is an important aspect, because beyond accounting rules they should provide private persons acting as entrepreneurs with additional options for the assessment of taxes. These options are to result in methods that impose smaller burdens on entrepreneurs.

In Hungary and Slovak Republic, several tax assessment methods have been introduced to enable entrepreneurs to handle taxation matters independently, while on the other hand these methods have been designed to involve incentive factors, too. This paper has the goal to examine the tax assessment methods in the two selected countries. In the first step, these methods will be characterized, and the differences will be identified. The principal focus is on the determination of the tax base. Just as importantly, we want to point out the importance of natural persons by examining secondary data.

\section{Literature review}

Taxation is traditionally regarded as the sector of the public law through which governments raise revenue needed for their justifiable distributive aims. The rules of tax law, in this view, control the manner in which governments raise revenue, while rules of transfer guide government spending (Paul et al., 2006). Personal income taxes are important sources of public revenues as currently revenues from personal income taxes account for nearly a quarter of total taxation on average, namely $24 \%$ in OECD countries (OECD, 2013a) and $21 \%$ in EU-27 (European Commission, 2013b). The tax structure is a very important aspect of the concept of the quality of taxation (Szarowszká, 2014).

Income reveals the consumption and saving potential of a person as well as the socio-economic development of a state. Taxation of income is related to the welfare of inhabitants - the higher the taxes, the smaller the amount of income at an individual's disposal. It is also related to the welfare of the state - direct taxes are one of its main sources of revenue. Income taxation is one of the most complicated elements of the state tax policy - it is the goal of the state to ensure sufficient revenue into the state budget as well as create a favorable labour taxation environment (high tax on labour income stimulates migration of the labour force and, when generous social policy comes along, it encourages living on benefits) (Skačkauskiené and Tunčikiené, 2014).

The aim of the individual income tax is to collect the individuals' contributions to the public expenses and to guarantee tax revenue for the state and local government budgets (Sztanó and Kis, 2013)

\footnotetext{
${ }^{1}$ Faculty of Economics, J. Selye University, Komárno, Slovakia, ngyurian@gmail.com

${ }^{2}$ Faculty of Economics, J. Selye University, Komárno, Slovakia, szobi.adam@gmail.com

${ }^{3}$ Faculty of Economics, J. Selye University, Komárno, Slovakia, angelika.kutna@gmail.com

${ }^{4}$ Faculty of Economics, J. Selye University, Komárno, Slovakia, dnhalasi@ gmail.com
} 
Income tax acts as a tool to achieve a Balanced Socio-Economic Growth by providing various concessions and incentives. Every person whose total income for the previous year exceeds the taxable limit is liable to pay income tax to the Central Government during the assessment year. Income tax will be charged for the income of the previous financial year at the prescribed rate in the current financial year (Hariharan, 2017).

Prescott (2004) has identified the significance of tax rates in accounting for differences in labor supply for the major advanced industrial countries. Prescott's idea was defended by the statistical evidence of Davis and Henrekson (2003), who found that in wealthier countries a large labor supply leads to higher tax rates. Alberto et al. (2005) found that the impact of taxes on labor supply is negated by unionization management and labor market regulation (Nadirov and Aliyev, 2016).

\section{Data and methodology}

The main goal of this paper is to look into and compare the opportunities that private entrepreneurs have in the Slovak Republic and Hungary from the perspective of the quantification of their taxes. To accomplish this goal the legal regulations pertaining to the specific taxes were studied, and then secondary data was processed. To write this paper, domestic and international scientific literature was surveyed, and further information was sourced from Eurostat and OECD statements. On a theoretical level, the options that are available for private entrepreneurs to assess their taxes in Hungary and the Slovak Republic have been analyzed. On the practical level, personal income tax proceeds were examined, and the significance of these revenues in the state budgets were pointed out. We have also paid attention to studying contributions.

\section{The assessment of tax determination opportunities of private entrepreneurs in Hungary and the Slovak Republic}

For individual activities, the taxable person and the taxpayer are the same entity. It means that private persons are required to settle the incomes generated in these operations with the state. In order to assess and state the amounts of tax, it is necessary to document and keep records of the factors that influence the tax base of the private person. The administration burdens associated with the maintenance of such records are shouldered by the private person. Therefore, the extent to which records need to be kept does have significance. Both in Hungary and the Slovak Republic, legal regulations offer several options to private persons pursuing individual activities. The following section of this paper focuses on the description of these options.

\section{Itemized statement of costs}

In Hungary, private entrepreneurs are obliged to keep the basic records in a form that can serve as grounds - even with respect to detailed records - for the tracking of all the economic events that result in cash revenues or expenses in association with their operations as private entrepreneurs in a closed system. Only those detailed records are to be kept that affect the tax base.

Unlike business operators belonging to the scope of the Accounting Act, revenues and costs have to be determined fundamentally from the perspective of cash flows. The only exception to this rule is depreciation, which follows the requirements of the Accounting Act with certain alterations.

For the purposes of Act LII of 2018, tax payment obligations are applicable to incomes that are taken into consideration in the calculation of the tax base that is deemed to be a part of the consolidated tax base within the meaning of Act CXVII of 1995 on personal income tax. The social contribution tax rate is 19.5 percent.

Quantification of the annual taxes of private entrepreneurs in Hungary

\begin{tabular}{|l|}
\hline Gross revenues \\
\hline \pm Items adjusting revenues \\
\hline - Costs incurred with sales \\
\hline = Taxable income \\
\hline - Items decreasing the income \\
\hline = Tax base (minimum $2 \%$ of revenues) \\
\hline * Tax rate (9\%) Entrepreneurial income after taxation \\
\hline = Income tax payable \pm Adjusting items \\
\hline
\end{tabular}

Source: Act CXVII of 1995 
Quantification of the annual taxes of private entrepreneurs in Slovak Republic

\begin{tabular}{|l|}
\hline Taxable income \\
\hline - Contributions \\
\hline = Partial tax base \\
\hline - Tax allowances \\
\hline = Modified tax base \\
\hline$*$ Tax rate $(19 \%, 25 \%)$ \\
\hline$=$ Annual tax \\
\hline \pm Adjusting items (tax bonus) \\
\hline = Income tax payable \\
\hline
\end{tabular}

Source: Act 595 of 2003

This method is known as "tax record-keeping" in the Slovak Republic. The scope of such records is determined in Section 11 of Article 6 of the Slovakian Income Tax Code. In this case, private persons are obliged to maintain records of their cash revenues, expenses, tangible assets and intangible assets included in commercial assets, inventories, receivables and payables.

\section{Flat rate taxation}

In Hungary, the rules pertaining to flat rate taxation are set out in Article 50-57 of the Act on personal income tax, stating that in relation to any fiscal year private entrepreneurs may choose flat rate taxation for the entire year. In the fiscal year preceding the commencement of flat rate taxation, the amount of the private person's entrepreneurial revenues may not be larger than HUF 15 million, and similarly the amount of revenues expected to be generated in the fiscal year concerned as a private entrepreneur cannot exceed HUF 15 million. The value limit is HUF 100 million in case the private entrepreneur is solely involved in retail operations. The contribution payment obligations of private entrepreneurs relying on flat rate taxation depend on the fact whether they have any other employment relations. Full-time private entrepreneurs are to pay the social contribution tax and other contributions in an amount corresponding at least to the typical earnings from the given activities.

To calculate the lump sum amount of the income, entrepreneurial revenues have to be taken into account without any reduction with discounts. From these revenues, the amount of the income can be determined by deducting certain cost rates (flat rate costs) defined in percentages for the specific activities. Flat rate costs associated with the individual activities:

- Under the generally applicable requirements, the amount of the income can be established after the deduction of 40 percent flat rate costs - or 25 percent flat rate costs for complementary activities - from revenues in relation to any activity.

- Eligible flat rate costs account for 80 percent of revenues - or 75 percent in the case of complementary activities - if the entrepreneur has pursued solely the industrial, agricultural, service and commercial activities listed in the Act during the entire fiscal year.

- From the revenues of private entrepreneurs involved in retail operations, 87 percent flat rate costs - or 83 percent for complementary activities - are deductible to state the amount of the income.

Article 6 of the Income Tax Code regulates the conditions and form of the application of flat rate taxation in the Slovak Republic. The key condition is that the entrepreneur cannot be registered for VAT during the period when flat rate taxation is applied. For continuous entrepreneurial activities, the eligible flat rate costs account for 60 percent. Additionally, the tax base is also decreased by the paid amount of contributions. In the case of complementary activities, the amount of the income can be determined by deducting 25 percent as flat rate costs.

\section{Simplified entrepreneurial tax}

This method is available for taxpayers whose annual revenues, including the amount of the valueadded tax, do not exceed HUF 30 million. Essentially, it requires the payment of 37 percent tax to discharge taxpayers from their tax payment obligations in all the other tax categories. The simplified entrepreneurial tax as a form of taxation that can be chosen only by the taxable persons listed in Act XLIII of 2002 on simplified entrepreneurial tax, such as private entrepreneurs, one person companies, limited partnerships, limited liability companies, etc. Businesses could opt into the simplified 
entrepreneurial tax at the end of 2018 for the last time. Thereafter, this tax category cannot be newly chosen, tough this tax status has not been canceled, but can be continued to be applied.

\section{Small business tax}

In practice, it is abbreviated as "KIVA" (meaning small business tax). It is regulated in Act CXLVII of 2012 on the itemized tax of small taxpayer enterprises and small companies. Small business tax can be chosen by companies, business associations and cooperatives where the headcount of employees is at maximum 50 persons, and the annual amount of sales revenues does not exceed HUF 1 billion, or the corresponding pro rata amount for any fiscal year that is shorter than one calendar year. Another condition is that the tax number of the enterprise cannot have been effectively canceled or suspended by the national tax authority during the two calendar years preceding the current fiscal year, and the balance sheet total in the taxpayer's report to be prepared in relation to fiscal year preceding the current fiscal year is expected to be not more than HUF 1 billion. As a main rule, the base of the small business tax equals to the amount of the balance of capital transactions and dividends with the addition of the amount of personnel expenditures, but at least the amount of personnel expenditures. The tax rate corresponds to 13 percent of the tax base. The taxable person belonging to the scope of small business tax is discharged from the assessment, statement and payment of the corporate income tax, social contribution tax and vocational training contribution. This form of taxation is applicable only in Hungary, but not in the Slovak Republic.

\section{Small taxpayers' itemized tax}

This studied method is also applicable in Hungary. Based on the legal regulations in effect, it cannot be used in the Slovak Republic. The method is associated with the "KATA" (meaning small taxpayers' itemized tax) abbreviation and is regulated in the above-referenced Act on the itemized tax of small taxpayer enterprises and small companies. If a private entrepreneur, one person company, or a limited or general partnership having solely private person members decides to choose KATA for taxation, with the payment of a monthly amount of HUF 50,000 tax in relation to full-time small taxpayers or HUF 25,000 for small taxpayers who are not deemed to be full-time entrepreneurs,

- small taxpayer limited partnerships become discharged from the payment of personal income tax, corporate income tax, social contribution tax, vocational training and health contribution,

- small taxpayer private enterprises and one person companies are exempted from personal income tax, social contribution tax, pension contribution, health insurance and labour market contribution, as well as the healthcare service contribution.

\section{The role of personal income tax among the proceeds of the state budget}

Incomes from independent activities are integral parts of the personal income tax both in Hungary and the Slovak Republic. Table 1 demonstrates to what extent personal income tax proceeds have added to the revenues of state budgets of the studied countries. It can be seen that substantially larger revenues have been achieved in Hungary. It is primarily due to the larger population. In view of the annual trends of revenues, continuous and steady increase can be seen in the Slovak Republic. From 2009 until 2011, Hungary witnessed consistent decline. It is apparent that personal income tax proceeds were at their nadir in 2011. Since 2014, the rise has been continuous.

\begin{tabular}{|c|c|c|c|c|c|c|c|c|}
\hline Table 1: Tax revenues from personal income tax in the period of 2009-2016 (EUR million) \\
\hline & $\mathbf{2 0 0 9}$ & $\mathbf{2 0 1 0}$ & $\mathbf{2 0 1 1}$ & $\mathbf{2 0 1 2}$ & $\mathbf{2 0 1 3}$ & $\mathbf{2 0 1 4}$ & $\mathbf{2 0 1 5}$ & $\mathbf{2 0 1 6}$ \\
\hline$S K$ & 1793.69 & 1789.57 & 1999.88 & 2122.78 & 2144.07 & 2275.12 & 2463.64 & 2682.07 \\
\hline$H U$ & 7130.05 & 6363.84 & 4520.67 & 5549.20 & 5421.25 & 5403.79 & 5743.74 & 5982.09 \\
\hline
\end{tabular}

The following examines the rate of personal income tax revenues from the incomes of independent entrepreneurs. In the Slovak Republic, the corresponding values range between 4.0 and 5.0. For Hungary, these values were in a consistent rise from 2009 until 2013. In the other studied years, they were over 5.3.

Table 2: Tax revenues from personal income tax per person in the period of 2009-2016 (EUR)

\begin{tabular}{|c|c|c|c|c|c|c|c|c|}
\hline & $\mathbf{2 0 0 9}$ & $\mathbf{2 0 1 0}$ & $\mathbf{2 0 1 1}$ & $\mathbf{2 0 1 2}$ & $\mathbf{2 0 1 3}$ & $\mathbf{2 0 1 4}$ & $\mathbf{2 0 1 5}$ & $\mathbf{2 0 1 6}$ \\
\hline$S K$ & 333,25 & 331,99 & 370,87 & 392,79 & 396,26 & 420,08 & 454,43 & 494,28 \\
\hline$H U$ & 710,80 & 635,47 & 452,71 & 558,72 & 547,11 & 547,09 & 582,79 & 608,52 \\
\hline
\end{tabular}


Table 2 shows the evolution of the personal income tax per capita. As it shown in the table, the amount of tax revenue per capita in Hungary is significantly higher than in the Slovak Republic. The biggest difference is in 2009. In the case of the difference, a continuous decrease can be observed during the examined years.

Table 3: Personal income tax revenue allocated to income of the self-employed (\% of total revenue
of personal income tax)
\begin{tabular}{|c|c|c|c|c|c|c|c|c|}
\hline & $\mathbf{2 0 0 9}$ & $\mathbf{2 0 1 0}$ & $\mathbf{2 0 1 1}$ & $\mathbf{2 0 1 2}$ & $\mathbf{2 0 1 3}$ & $\mathbf{2 0 1 4}$ & $\mathbf{2 0 1 5}$ & $\mathbf{2 0 1 6}$ \\
\hline$S K$ & 4.6 & 4.2 & 5.0 & 4.3 & 4.7 & 4.8 & 4.6 & 4.0 \\
\hline$H U$ & 3.3 & 3.8 & 5.5 & 5.6 & 5.7 & 5.5 & 5.6 & 5.3 \\
\hline
\end{tabular}

Source: European Commission services

This paper also has the intention to examine contributions. The outcomes of this latter study are presented in Table 4 and Table 5. Table 4 shows trends in total revenues. The values for tax proceeds are inclusive of contribution revenues, as well. In the 28 Member States of the European Union, $€ 5,791,520.6$ million tax revenues were collected in 2016 by the imposition of personal income tax. This sum underpins the importance of the studied tax category. From among the studied states, Hungary had the largest share from the given amount, as nearly $€ 44,747.5$ million tax proceeds were recorded in 2016 owing to wage-related taxes.

\begin{tabular}{|} 
Table 4: Total taxes (including compulsory actual social contributions) as \% of GDP \\
$\qquad$\begin{tabular}{|c|c|c|c|c|c|c|c|c|c|}
\hline & $\mathbf{2 0 0 9}$ & $\mathbf{2 0 1 0}$ & $\mathbf{2 0 1 1}$ & $\mathbf{2 0 1 2}$ & $\mathbf{2 0 1 3}$ & $\mathbf{2 0 1 4}$ & $\mathbf{2 0 1 5}$ & $\mathbf{2 0 1 6}$ & $\begin{array}{c}\text { Revenue } \\
\mathbf{2 0 1 6}\end{array}$ \\
\hline$E U-28$ & 37.1 & 37.2 & 37.7 & 38.3 & 38.7 & 38.7 & 38.5 & 38.9 & $5,791,520.6$ \\
\hline$E A-19$ & 38.0 & 37.9 & 38.5 & 39.5 & 40.0 & 40.1 & 40.0 & 40.1 & $4,327,402.0$ \\
\hline$S K$ & 28.8 & 28.0 & 28.5 & 28.2 & 30.1 & 31.0 & 32.1 & 32.2 & $26,140.2$ \\
\hline$H U$ & 38.9 & 37.2 & 36.6 & 38.3 & 37.9 & 38.1 & 38.8 & 39.3 & $44,747.5$ \\
\hline
\end{tabular}
\end{tabular}

Source: DG Taxation and Customs Union, based on Eurostat data

The next step is to have a look into personal income tax proceeds without contributions. In the 28 Member States of the European Union, $€ 4,000,058.1$ million tax revenues were collected in 2016 by the imposition of personal income tax. This means that contributions accounted for $€ 1,791,462.5$ million. Therefore, it can be claimed that contributions as proceeds to the state budget cannot be ignored, either.

\begin{tabular}{|c|c|c|c|c|c|c|c|c|c|c|}
\hline & & 2009 & 2010 & 2011 & 2012 & 2013 & 2014 & 2015 & 2016 & $\begin{array}{c}\text { Revenue } \\
2016\end{array}$ \\
\hline & $E U-28$ & 25.0 & 25.3 & 25.7 & 26.3 & 26.6 & 26.7 & 26.7 & 26.8 & $4,000,058.1$ \\
\hline & EA-19 & 24.2 & 24.2 & 24.7 & 25.5 & 26.0 & 26.1 & 26.1 & 26.1 & $2,817,454.0$ \\
\hline & $S K$ & 16.4 & 15.9 & 16.4 & 15.8 & 16.8 & 17.6 & 18.3 & 18.1 & $14,703.8$ \\
\hline & $H U$ & 26.1 & 25.4 & 23.7 & 25.4 & 25.1 & 25.3 & 25.8 & 25.8 & $29,323.9$ \\
\hline
\end{tabular}

Source: DG Taxation and Customs Union, based on Eurostat data

\section{Conclusion}

Having examined the methods of tax assessment for private entrepreneurs in Hungary and the Slovak Republic, it is apparent that there are various options available for taxpayers in both countries. Beyond the effective accounting regulations, the Slovak Republic and Hungary offers the application of 2 and 5 methods, respectively, under rigorous requirements. Differences can be seen in relation to the items decreasing the tax base, as well as the rates of taxes and contributions. In view of tax rates, all the methods that are applicable to Hungary allow the use of linear tax rates. On the other hand, Slovak Republic has adopted progressive taxation regimes. The tax base carries $19 \%$ tax up to $€ 36,256.37$, whereas the tax rate for amounts over this limit value is $25 \%$.

The studied secondary data prove that personal income tax is a very important tax category in the state budgets of all countries. In the 28 Member States of the European Union, $€$ 5,791,520.6 million tax revenues were collected in 2016 by the imposition of taxes on wages and salaries. It is a crucial fact that should encourages all the Member States of the European Union to pay sufficient attention to personal income tax. 


\section{Acknowledgments}

This study was supported by the Pallas Athéné Domus Educationis Foundation.

\section{References}

Alberto, F. A., Edward L. G., Bruce, S. (2005). Work and Leisure in the U.S. and Europe: Why so Different?. NBER Macroeconomics.

Davis, S. J., Henrekson, M. (2003). Tax effects on work activity, industry mix and shadow economy size: Evidence from rich-country comparisons. Manuscript. University of Chicago Graduate School of Business.

Hariharan, N. (2017). Income Tax Law \& Practice. Publisher: MCGRAW-HILL EDUCATION (INDIA).

Nadirov, O., Khatai, A. (2016). Motivation to Work, Labor Income Taxes and Life Satisfaction: Hungary, Estonia, Continental Europe and the United States. Procedia Economics and Finance, 39, 373-379.

Paul, E. F, Miller, F. D., Paul, J. (2006) Taxation, Economic Prosperity, and Distributive Justice. Cambridge University Press.

Prescott, E. C. (2004). Why do Americans work so much more than Europeans? Federal Reserve

Skačkauskiené, I., Tunčikiené, Ž. (2014). Comparative Evaulation of the Labour Income Taxation in the Baltic States. Procedia - Social and Behavioral Sciences, 110, 439-449.

Szarowszká, I. (2014). Personal Income Taxation in a Context of a Tax Structure. Procedia Economics and Finance, 12, $662-$ 669.

Sztanó, I., Kis, T. (2013) Adózás, társadalombiztosítás, támogatás [Taxation, Social Security, Subsidies] [online]. Digitális Tankönyvtár [Digital Textbook Repository]. Retrieved from http://www.tankonyvtar.hu/hu/tartalom/tamop412A/0007_d6_1100_1101_1103_adozas_tb_scorm/adatok.html. 